\title{
The Relationship between Dietary Patterns and Nutritional Knowledge with the Nutritional Status of Bajo Tribe Pregnant Women in Duruka District, Muna Reqency
}

\author{
Trees", Saktian Taskawati2 \\ ${ }^{1,2}$ Department of Nutrition, Polytechnic of Health Kendari, Ministry of Health Republic of Indonesia. \\ DOI: https://doi.org/10.24321/2455.9199.201817
}

\section{Abstract}

Nutritional status of pregnant women is strongly influenced by food intake and the presence of an infectious disease. Another factor that also affects the nutritional status of pregnant women is the diet and nutritional knowledge of pregnant women. This study aims to determine the relationship of diet and nutrition knowledge with nutritional status of bajo tribe pregnant women in Muna Regency, Southeast Sulawesi Province. This study is an analytical study with approach cros sectional study. The number of samples selected is 35 people. Sampling by total sampling method. The data collection was done by interview using questionnaire tools. The results of the study showed that the diet of pregnant women was mostly $60 \%$ classified as poor, and the knowledge of pregnant women was mostly $54.3 \%$ classified as lacking. The results of statistical analysis using the test chi-square showed that between diet and nutritional status of pregnant women $(p=0.023)$, between the level of knowledge with the nutritional status of pregnant women $(p=0.730)$. There is a significant relationship between dietary pattern and nutritional status of pregnant women, and there is no significant relationship between the level of knowledge with the nutritional status of pregnant women.

Keywords: Dietary Pattern, Nutritional Status
\end{abstract}

\section{Introduction}

Public health problems in Indonesia are currently facing nutritional problems. ${ }^{1}$ One group prone to malnutrition is pregnant women. The period of pregnancy is a period where more nutrients are needed for the mother than non-pregnant. ${ }^{2}$ If the needs of pregnant women are not fulfilled, it will have a negative impact on the mother and fetus. The fetus can experience disability or be born with a low birth weight. ${ }^{3,4}$ Pregnant women who are lack of protein and micronutrinet (iron, zinc and magnesium) are at risk for the occurance of low birth weight babies. ${ }^{5,6}$ While pregnant women having excess nutrients are at risk for the macrosomia in the fetus. ${ }^{7,89}$ Pregnant women with severe malnutrition fetuses are at risk malnutrition fetuses are at risk of low birth weight and intrauterine growth restriction (IUGR), diabetes, hypertension, atherosclerosis, and dyslipidemia. ${ }^{10,11,12}$

During pregnancy, if there is Chronic Energy Deficiency (CED) in pregnant women, there can be a greater risk of morbidity than normal pregnant women. This has an impact on the risk of giving birth to a low birth weight baby, death during childbirth, and bleeding. ${ }^{3} \mathrm{~A}$ post-census survey in 1993 reported that $30 \%$ of pregnant women suffered from CED due to decreased food consumption. National health research results in 2010 nationally the prevalence of Chronic Energy Deficiency in pregnant women was $21.6 \%$, and for Southeast Sulawesi was $27.5 \%$. The results of the Southeast Sulawesi Provincial Health Office survey in 2011 found that

Corresponding Author: Trees, Department of Nutrition, Polytechnic of Health Kendari, Ministry of Health Republic of Indonesia. E-mail Id: trees18kendari@gmail.com

Orcid Id: https://orcid.org/0000-0002-0082-2608

How to cite this article: Trees, Taskawati S. The Relationship between Dietary Patterns and Nutritional Knowledge with the Nutritional Status of Bajo Tribe Pregnant Women in Duruka District, Muna Regency. Int J HealthCare Edu \& Med Inform 2018; 5(4): 7-11. 
pregnant women with CED status in Muna Regency were $34.5 \%$, while in 2012 the prevalence of CED in pregnant women in Muna District was $35.6 \% .^{13}$

The increasing prevalence of Chronic Energy Deficiency is one of the effects of a prolonged economic crisis that caused a food crisis, both a production crisis and a purchasing power crisis, which caused nutritional problems which were very concerning, namely the deterioration of the nutrition condition of the community, especially in high-risk groups such as pregnant women and nursing mothers. ${ }^{7,14}$ The low nutritional status and wrong diet in pregnant women can lead to nutritional disorders such as anemia, lack of weight gain in pregnant women, and growth disorders. ${ }^{15,16}$

The problem with Bajo people who live in Muna Regency is the lack of Bajo people. This is because the Bajo people have a livelihood as traditional fishermen. This condition causes them sometimes to lack food, so that it is a vulnerable group for malnutrition. They are more likely to go to sea to increase family income. This has become a factor in the lack of Bajo people who have received education. This condition causes a lack of knowledge of the Bajo community regarding nutrition issues.

The importance of nutritional knowledge shows that nutritional status is sufficient to influence family health and well-being, because with adequate knowledge of maternal nutrition it will be able to choose and provide food that is sufficiently nutritional according to the needs of the body. The lack of knowledge about food needs among the Bajo tribe is caused by the fact that the Bajo people are generally reluctant to go to school.

The results of research reported by Rahmaniar. ${ }^{17}$ Stated that one of the causes of the emergence of nutritional disorders is a lack of nutritional knowledge in daily life. Based on Rahmaniar's research, ${ }^{17}$ Mamuju District had $18.8 \%$ pregnant women with low levels of knowledge who suffered from chronic energy deficiency.

In addition to the level of mother's knowledge, diet is one of the factors that affect an individual's nutritional status. Diet is very different from each region because it is influenced by customs. These factors, among others, will affect both the production of vegetable and animal foods and their consumption patterns. The level of one's consumption is influenced by many factors, one of which is the level of nutritional knowledge of pregnant women. The daily diet of pregnant women is also influenced by the presence of cultural factors, namely the existence of dietary restrictions on the grounds that if consumed during pregnancy will result in disability in babies born so that food intake in pregnant women becomes reduced.

Pregnant women who suffer CED will affect the baby they contain such as fetal growth that is less than optimal even causes death in infants. Arisman [18] suggested that women who suffer from malnutrition before pregnancy or during the first week of pregnancy tend to give birth to babies who suffer brain damage and bone marrow because the central nervous system is very sensitive in the first 2-5 weeks. Malnourished mothers during the last week of pregnancy will give birth to babies with low birth weight (LBW) (<2500 g), because a lot of fat is stockpiled during the third trimester. ${ }^{18}$

Based on the description above, it is necessary to examine the relationship between dietary patterns and the level of knowledge of maternal nutrition with nutritional status of bajo tribe pregnant women in Lagasa village, Duruka district, Muna regency.

\section{Research Methods}

A total Type of research is analytic research with the approach Cross Sectional Study. This research was conducted in October 2013, in Lagasa Village, Duruka District, Muna Regency. The population in this study were all existing Bajo tribe pregnant women and lived in the Lagasa Village, Duruka District, Muna Regency. The sample in this study were pregnant women with Bajo tribe who lived and lived in the Lagasa Village, Duruka District, Muna Regency. Sampling was done by total sampling method with 35 people.

General description of the sample and level of nutritional knowledge were obtained through interviews using a questionnaire. Nutritional status of pregnant women is obtained through measurement of the Upper Arm Circumference using the upper arm circumference band.

\section{Results}

\section{Univariat analysis characteristic of respondent}

Table 1 show the characteristic of respondent include variable diatery patterns and Knowledge level:

Table 1.Characteristic of respondent

\begin{tabular}{|c|c|c|}
\hline Variable & Number & $\%$ \\
\hline Dietary patterns & 14 & 40 \\
\hline $\begin{array}{c}\text { Dietary patterns for pregnant } \\
\text { women category enough }\end{array}$ & 21 & 60 \\
\hline $\begin{array}{c}\text { Diet for pregnant women less } \\
\text { category }\end{array}$ & 16 & 45.7 \\
\hline Knowledge Level & 19 & 54.3 \\
\hline Enough & & \\
\hline Less & & \\
\hline
\end{tabular}

\section{Relationship between dietary patterns with nutritional} status

This study analyzes the relationship of dietary variables with nutritional status to namely to see the closeness of the relationship between the two variables. For distribution of samples according to diet and nutritional status of pregnant women can be seen in the following table. 
Table 2.Relationship of Dietary patterns with the Nutritional Status Pregnancy

\begin{tabular}{|c|c|c|c|c|c|c|}
\hline \multirow{2}{*}{ Diet } & \multicolumn{3}{|c|}{ Nutritional Status } & \multicolumn{2}{c|}{ Total } \\
\cline { 2 - 6 } & \multicolumn{2}{|c|}{ CED } & \multicolumn{2}{c|}{ Normal } & \multicolumn{2}{c|}{} \\
\cline { 2 - 6 } & $\mathbf{N}$ & $\%$ & $\mathbf{n}$ & $\%$ & $\mathbf{n}$ & $\%$ \\
\hline Sufficient & 1 & 7.1 & 13 & 92.9 & 14 & 100 \\
Less & 10 & 47.6 & 11 & 52.4 & 21 & 100 \\
\hline Total & 11 & 36.7 & 24 & 100 & 35 & 100 \\
\hline \multicolumn{6}{|c|}{$p=0.023$} \\
\hline
\end{tabular}

Table 2 shows that of the 14 pregnant women with adequate dietary patterns, most of them were $92.9 \%(n=13)$ nutritional status of normal pregnant women, while of 21 pregnant women with a pattern eat less than most $51.4 \%$ $(n=11)$ nutritional status of pregnant women is normal. There were also pregnant women who suffered from CED (Chronic Energy Eficiency) in the amount of $47.6 \%(n=10)$ with less diet.

The results of statistical tests using chi-square and followed by fisher test because one of the cell contents is insufficient value of 5 so that the fisher's test value ( $p$-value $=0.23$ ) shows there is a significant relationship between diet and nutritional status of pregnant women.

\section{Relationship Between Knowledge Level and Nutritional Status of Pregnant Women}

Distribution of samples according to knowledge and nutritional status of pregnant women can be seen in the following table.

Table 3.Relationship of Knowledge with Nutritional Status of Pregnant Women

\begin{tabular}{|c|c|c|c|c|c|c|}
\hline \multirow{2}{*}{$\begin{array}{c}\text { Knowledge } \\
\text { of }\end{array}$} & \multicolumn{3}{|c|}{ Nutritional Status } & \multicolumn{2}{c|}{ Total } \\
\cline { 2 - 6 } & \multicolumn{2}{|c|}{ CED } & Normal & \multicolumn{1}{c|}{} \\
\cline { 2 - 6 } & N & $\%$ & n & $\%$ & n & $\%$ \\
\hline Sufficient & 6 & 37.5 & 10 & 62.5 & 16 & 100 \\
Less & 5 & 26.3 & 14 & 73.7 & 19 & 100 \\
\hline Total & 11 & 31.4 & 24 & 68,6 & 35 & 100 \\
\hline \multicolumn{7}{|c|}{$p=0.730$} \\
\hline
\end{tabular}

Table 3 shows that out of 16 pregnant women with sufficient knowledge, most of $62.5 \%$ of pregnant women had normal nutritional status, while of the 19 pregnant women with less knowledge most of them were $73.7 \%$ normal nutrition.

The results of statistical tests using chi-square obtain value $p=0.730$ shows no significant relationship between knowledge and nutritional status of pregnant women.

\section{Analysis}

Relationship between Diet and Nutritional Status of Pregnant Women

The daily diet of pregnant women is also affected by the presence of cultural factors there is a belief in challenging certain foods for consumption on the grounds that if consumed during pregnancy will result in disability in babies born so that food intake in pregnant women becomes less. Food for pregnant women must be in accordance with the needs of foods that are balanced with the development of pregnancy. Pregnant women with poor nutritional status tend to give birth to babies with low birth weight and a greater risk of death compared to babies born to mothers of normal weight. ${ }^{19,20}$

Deficiency of micronitrient intake in pregnant women can lead to anemia in pregnant women, maternal mortality and low birth weight. ${ }^{5}$ To the fetus the influence of protein is not so great because the fetus takes from the mother's body but if the lack of the amount exceeds the limit it can cause miscarriage. ${ }^{21}$ According to Andonotopo ${ }^{22}$ if there are nutritional limitations during pregnancy, it can lead to premature birth and long-term negative effects.

Lime per day is needed by every ordinary swoman as much as $40 \mathrm{mg} / \mathrm{kg}$ body weight. During pregnancy the mother's needs will increase to $75 \mathrm{mg} / \mathrm{kg}$ body weight. In addition, it is also necessary to consume foods that contain lime such as milk, cheese and peanut leaves. ${ }^{21}$

Iron needed by women 5-10 mg/ day, while pregnant women need about $15 \mathrm{mg} /$ day where iron is the most important mineral because iron is needed in the formation of red blood cells, because if iron deficiency will cause less blood disease. For that, during pregnancy, a woman is advised to consume Fe tablets regularly 1 tablet 1 day to anticipate the possibility of anemia both during pregnancy and postpartum. ${ }^{21}$ The increased risk of complications of pregnant women and birth defects can be caused by iron, zinc and folic acid deficiency. ${ }^{23}$ Anemia deficiency iron can increase the rate of premature delivey and perinatal mortality. ${ }^{24}$ It was also reported that folic acid deficiency during pregnancy is a contributing factor to anemia in pregnant women. ${ }^{25,26}$

Pregnancy is a period where the nutritional elements needed by a woman are more than what is needed in normal circumstances. This is because the mother during pregnancy occurs the growth process, namely the growth of the fetus that is in the womb and the growth of various organs of the supporting mother of pregnancy. During pregnancy the mother needs additional food about 50\% of the usual, especially egg white, lime, phosphorus, iron and vitamins-vitamins.

From the results of the study showed that of the 14 pregnant women with a diet classified as sufficient, most of them were $92.9 \%(n=13)$ nutritional status of normal pregnant women, while of 21 pregnant women with a diet classified as less, most were $51.4 \%$ ( $n=11)$ Nutritional status of pregnant women is normal. There were also pregnant women who suffered from CED in the amount of $47.6 \%$ $(n=10)$ with poor diet. 
The results of statistical tests using chi-square and followed by fisher test because one of the cell contents is insufficient value of 5 so that the fishery test value $(p$-value $=0.23)$ shows a significant relationship ( $p$-value $<0.05$ ) between diet with the nutritional status of pregnant women.

The consumption pattern of pregnant women is very important to note given that if a pregnant woman is malnourished it can have a negative impact on the mother herself and on the baby they conceive. Negative impacts include causing death, pregnant poisoning (Toxemia), miscarriages, babies Birth dead, low birth weight (LBW).

\section{Relationship of knowledge with nutritional status of pregnant women}

Nutritional knowledge is the process of learning about food how our bodies use it as needed with a view to achieve their level of health and well-being. ${ }^{27}$

The results showed that out of 16 pregnant women with sufficient knowledge, most of $62.5 \%$ of pregnant women had normal nutritional status, while of the 19 pregnant women with knowledge classified as lacking, most of them were $73.7 \%$ with normal nutritional status.

The results of statistical tests using chi-square obtainedvalue $p=0.730$ shows no significant relationship $(p>0.05)$ between knowledge and nutritional status of pregnant women.

From the data above shows that pregnant women with a low level of knowledge tend to have normal nutritional status. The large percentage of maternal nutritional knowledge that was lacking was also due to the low level of education of the mother, the majority (48.6\%) of the education level of pregnant women only graduated from elementary school.

In addition to low knowledge, the frequency of counseling to pregnant women is very low. From the results of interviews with mothers, they generally said that at the time of posyandu, nutrition counseling was rarely held by nutritionists and other health workers. Moehji. ${ }^{28}$ said that there are several factors that influence one's knowledge of nutrition, one of which is the frequency of counseling

Based on the data it can be seen that in mothers with sufficient knowledge, the proportion of nutritional status of pregnant women with good nutritional status is much greater than those of mothers with less knowledge. This illustrates that if the mother has sufficient nutritional knowledge, the nutritional status will be good too.

Knowledge of pregnant women is closely related to the way food is chosen and the pattern of daily eating habits of pregnant women. Knowledge of pregnant women especially regarding nutrition will affect the diet of pregnant women, which in turn affects the status of pregnant women. For pregnant women, sufficient knowledge is needed, especially regarding the selection and processing of food that is safe and sufficient to contain nutrients needed for fetal growth and development. According to Timmreck ${ }^{20}$ the higher education in women, the lower the infant and maternal mortality rates.

Nutritional knowledge that does not affect how to choose foods that contain lots of high-nutrient sources at affordable prices also affects how to choose food ingredients as inhibitors and boost absorption of nutrients so that not a lot of wasted nutrients are wasted. ${ }^{28}$

Maternal nutrition knowledge that does not greatly affect the quality of food served. In addition, lack of knowledge can cause errors in choosing the type of food that meets nutritional requirements. ${ }^{27}$ Maternal nutrition knowledge is very important, because it will affect the quality of food that will be given to toddlers.

With knowledge of nutrition and a sufficient level of income, the family will be able to provide enough food for the family for the needs of the body. Further stated Suharjo ${ }^{27}$ that with a good knowledge would cause the mother was able to pick and food processing, in terms of both taste and shape due to these circumstances can lead to increased food consumption, especially energy and protein.

Based on the description above, basically giving knowledge Nutritional status of pregnant women is part of an effort to optimize the ability of mothers, so that with good nutrition knowledge it is expected that pregnant women have good nutritional status.

\section{Conclusion}

This study shows a significant relationship between the diet of pregnant women and the nutritional status of pregnant women, and there is no significant relationship between the level of knowledge with the nutritional status of pregnant women.

\section{Conflict of Interest: None}

\section{Reference}

1. RI KK. Application of Food Consumption Patterns and Physical Activity. Jakarta: Ministry of Health of the Republic of Indonesia; 2012.

2. Andriani Z. Overview of Nutritional Status of Pregnant Women Based on the size of the upper arm circumference in Sukamaju Village, Depok City. Syarif Hidayatullah State Islamic University; 2015.

3. Marlenywati. Risk of Chronic Energy Deficiency (CED) in Pregnant Women Adolescents (Ages 15-19 Years) in Pontianak City in 2010. University of Indonesia; 2010.

4. Leffelaar ER, Vrijkotte TG, Eijsden MV. Maternal early pregnancy vitamin $D$ status in relation to fetal and neonatal growth: results of the multi-ethnic Amsterdam Born Children and their Development cohort. Britsh J Nutr 2010; 104(1): 108-117.

5. Wessells KR, Ouédraogo CT, Young RR et al. Micronutrient Status among Pregnant Women in with Deficiency. Nutrients 2017; 9(5): 430. 
6. Kassu A, Yabutani T, Mulu A et al. Serum Zinc, Copper, Selenium, Calcium, and Megnium Levels in Pregnant and Non-Pregnant Women in Gondar, Nortwest Ethiopia. Biol Trace Elem Res 2018; 122(2): 97-106.

7. Beard J. Iron requirements and adverse acomes. Handbook of Nutritions in Pregnancy. Cj LK, Sc C, EH P, editors. Totowa: MJ; Humana Press; 2008. 233-254.

8. Williamson CS. Nutritions Bulletin. Nutritions in Pregnancy 2006; 31(1): 28-59.

9. Drake A, Reynolds R. Impact of maternal obesity on off spring obesity and cardio metabolic disease risk. Reproduction 2010; 140(3): 387-398.

10. Wegierek D. Intrauterine nutritions; long term consequences for fascular health. Int J Womens's Heal 2014; 6(1): 647-656.

11. Wegierek D, Szamotulska K. Fetal development and risk of cardiovascular diseases and type 2 diabetes, in adult life. Med Wieku Rozw 2011; 15(3): 203-215.

12. Macleod J, Tang L, Hobbs FDR et al. Effects of Nutritional Supplementation during Pregnancy on Early Adult Disease Risk: Follow Up of Offspring of Participants in a Randomised Controlled Trial Investigating Effects of Supplementation on Infant Birth Weight. PLOS ONE 2013; 8(12): 1-16.

13. Southeast DS. Profile of the Southeast Sulawesi Health Office. 2014.

14. Thaha A. Protection of the human rights of the poor is reviewed from a nutritional, health perspective. In: scientific speech in the framework of IAKMI Musda center for nutrition and UNHAS Health. Makassar: UNHAS; 2002.

15. Chairunnita, Hardinsyah, Dwiriani C. Model for Estimating Baby Birth Weight based on Pelvic Circumference of Pregnant Women. A Nutrition and Food 2006; 1(2): 17-25.

16. Ojofeitimi E, Ogunjuyigbe P, Sanusi R et al. Poor Dietary Intake of Energy and Retinol Among Pregnant Women. J Nutr 2008; 7(3): 480-4.

17. Rahmaniar A, Nurpudji, Bahar B. Factors related to chronic energy deficiency in pregnant women in Tampa Padang, Mamuju District, West Sulawesi. Indonesian Nutrition Media 2013; 2(2): 99-103.

18. Arisman. Nutrition in the Life Cycle. Jakarta: Book of EGC Medicine; 2008.

19. Najoan JA, Manampiring A. Relationship between Socio-Economic Levels and Chronic Energy Deficiency in Pregnant Women in Kombos Barat Village, Singkil District, Manado City. 2011.

20. Timmreck C. Epidemiology of an Introduction. Job and Education as Character People. Jakarta: EGC Medical Book Publishers; 2005. 316-17 p.

21. Nasedul. Healthy food for pregnant women. Jakarta: Puspa Swara; 1999.

22. Andonotopo W, Arifin M. Lack of Nutrition in Pregnant Women: Threats to Fetus. 2005.

23. Seshadri S. Prevalence of micronutrient deficiency in particular in iron, zinc and folic acid in pregnant women in South East Asia. Br J Nutr 2011; 85(2): 87-92.

24. CBC, Salvador S, Patricia S. The Relationship Between Intimate Partner Violence and Unintended Pregnancy: Analysis of a National Sample From Colombia. International Perspectives on Sexual and Reproductive Health 2004; 30(4): 165-173.

25. Bhate V, Deshpande S, Bhat D et al. Vitamin B 12 status of pregnant Indian women and cognitive function in their 9-year-old children. Food Nutr Bull 2008; 29(4): 249-254.

26. López NJ, Smith PC, Gutierrez J. Higher risk of preterm birth and low birth weight in women with periodontal disease. J Dent Res 2002; 81(1): 58-63.

27. Suharjo. Various Ways of Nutrition Education. Bogor: Bumi Aksara; 1996.

28. Moehji. Science of nutrition. Jakarta: Bharatara; 1992.

Date of Submission: 2018-12-17 Date of Acceptance: 2019-03-11 